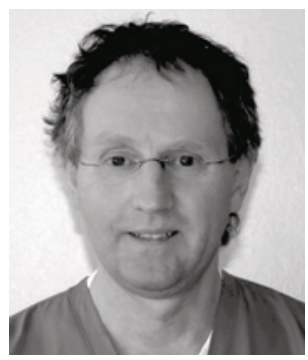

\section{Gunnar Engesnes}

En av frontfigurene i midtnorsk anestesi - Gunnar Engesnes - er gått bort, bare 58 år gammel.

Gunnar Engesnes begynte sin anestesikarriere ved daværende Regionsykehuset i Trondheim. Deretter begynte han som assistentlege ved Anestesiavdelingen, Innherred sykehus, i 1988. Etter hvert fikk han tilbud om spesialiststilling, og siden 1990 jobbet han som overlege ved sykehuset. I løpet av denne tiden hadde han også stilling som avdelingsoverlege fra 2003 til 2015.

Pasienten sto alltid i sentrum for Gunnar, og det gjennomsyret alle hans avgjørelser og håndtering av pasientene gjennom årene. Han hadde en egen evne til å formidle informasjon til pasienter og pårørende. Uansett om det var vanskelige samtaler eller generell preoperativ informasjon, hadde Gunnar en løsning som gjorde at pasienter og pårørende følte seg ivaretatt.

Gunnar hadde et spesielt hjerte for pasienter med kroniske smerteplager. Han var en viktig del av den tidligere smertepoliklinikken ved Innherred sykehus, og hadde alltid tid og gode råd når pasienter hadde smerteplager hvor konvensjonell terapi ikke strakk til.

På fritiden hadde Gunnar mange interesser. Han var en meget habil badmintonspiller og trivdes ute i naturen, spesielt på familiegården. Opp gjennom årene beriket han også både eget og andres hjem med mange kunstprosjekter. Gunnar jobbet for at Anestesiavdelingen ved Innherred sykehus, senere Sykehuset Levanger, skulle være en av de fremste i landet. Det skulle være spennende, givende og utviklende å begynne der som lege i spesialisering $i$ anestesi. Det er mange leger som i gjennom tiden har merket akkurat det. Vi lærte alle mye av hans måte å møte pasienter på. Hans væremåte, ro og fokus på å finne løsninger vil for alltid være et eksempel til etterfølgelse.

Den siste tiden var Gunnar plaget med sykdom. Han var likevel til stede og bidro helt til det siste med sin kunnskap og erfaring. Gjennom hans tilstedeværelse var det som om roen senket seg $i$ avdelingen og arbeidet kunne fortsette.

En stor anestesilege er gått bort, og han vil bli dypt savnet ved sykehuset. Våre tanker går til hans nærmeste i sorgen.

På vegne av kollegene ved Anestesiavdelingen, Sykehuset Levanger Håkon Trønnes

\section{MELDTE DØDSFALL}

Attila Endre Kovacs 23.8. 1935-7.11. 2015

Arne Ivar Østensen 8.3. 1940-20.11. 2015

Mogens Haaland 18.3. 1933-18.11. 2015

Oddleif Thorvald Lium 25.1. 1924-17.11. 2015

Åsa Rytter Evensen 11.8. 1942-6.11. 2015

Olav J. Gøystdal 4.10. 1941 -24.10. 2015

Hans J. Ånstad 17.7. 1932-31.8. 2015 